\title{
REDUCING TRAVEL RISKS
}

nformation on measures you can take to minimise

risks of infection during travel, especially to Third World countries, is available from a number of sources ${ }^{1,2,3}$. However, as disease patterns change quickly in different parts of the world, this guide has been prepared for those planning overseas travel.

Infections of most concern are either the commonest (eg. gut, respiratory infections) or those which are life threatening (eg. malaria, typhoid fever, yellow fever, AIDS).

The risks of infection may be reduced by:

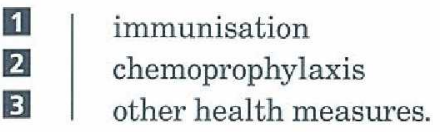

\section{IMMUNISATION}

Quarantinable diseases are infectious diseases which, by international agreement, can be isolated.

\section{Cholera}

The current cholera vaccine contains killed Vibrio cholerae. The protection rate is only about $60 \%$. This is not a very satisfactory vaccine, and is not recommended unless you are entering a country that requires cholera immunisation. These are Pakistan, Pitcairn and Sudan.

Two doses are required: $0.5 \mathrm{ml}$ subcutaneously, $1.0 \mathrm{ml} 2-4$ weeks later (minimum of one week between injections). The injection is best given in the evening. Two aspirin or paracetamol tablets should be taken before going to bed to minimise severity of possible local and systemic reactions.

The Certificate is valid for six months. After that, only a single booster is needed.

\begin{tabular}{|c|c|}
\hline \multicolumn{2}{|l|}{ TABLE 1} \\
\hline \multicolumn{2}{|c|}{$\begin{array}{l}\text { CHOLERA ENDEMIC AREAS } \\
\text { (AS AT SEPTEMBER, 1990) }\end{array}$} \\
\hline Africa: & $\begin{array}{l}\text { Algeria, Angola, Burundi, Cameroon, Cote } \\
\text { D'ivoire, Ghana, Guinea, Kenya, Liberia, Mali, } \\
\text { Mauritania, Mozambique, Niger, Nigeria, } \\
\text { Rwanda, Sao Tome, Tanzania, Zaire, Zambia. }\end{array}$ \\
\hline Asia: & $\begin{array}{l}\text { Bangladesh, Burma, China, India, Indonesia, Iran, } \\
\text { Kuwait, Malaysia, Nepal, Sri Lanka, Thailand, } \\
\text { Vietnam. } \\
\text { (Sometimes cholera occurs elsewhere, eg. Iraq, } \\
\text { Hong Kong, Singapore, Tuvalu.) }\end{array}$ \\
\hline Europe: & Romania. \\
\hline
\end{tabular}

\section{Yellow fever}

Immunisation is required if you are visiting known yellow fever endemic areas. It is also required by some countries, including Australia, of travellers returning from yellow fever areas. Recognised yellow fever areas are: Equatorial Africa from Angola in the south to
Senegal, Niger, Chad, Sudan, Mali, Ethiopia and Somalia inclusive to the north; Panama and tropical South American countries west of the Andes and to the north of Bolivia inclusive.

The yellow fever vaccine is a live, attenuated vaccine currently administered at a number of travel medical clinics ${ }^{4}$. The Certificate is valid for 10 years after the 10 th day following vaccination.

\section{Other infectious diseases}

Other infectious diseases against which immunisation is advisable include:

Typhoid fever

Typhoid fever is endemic in most countries of the world, but is far more prevalent in developing countries. If a lot of time is to be spent in such areas, or if you are going off the beaten track, typhoid vaccination is advisable.

It is suggested that the live, oral, attenuated vaccine be used. Dosage: One capsule swallowed whole on day 1, 3, 5 and 7 , one hour before a meal. This dosage should provide immunity for up to three years. NB Oral vaccine should not be taken with antibiotics or certain antimalarials, eg. doxycycline or Maloprim.

Alternatively, the parenteral vaccine could be used protective efficacy about $70 \%$. Dosage: Two subcutaneous injections of $0.5 \mathrm{ml} \mathrm{2-4}$ weeks apart; minimum period one week. The same measures as for cholera immunisation are suggested to reduce discomfort later.

Some people react severely to typhoid and cholera vaccines. With typhoid vaccine, adequate booster effect may be obtained by the intradermal injection of $0.1 \mathrm{ml}$ in the deltoid area, instead of subcutaneous administration.

The vaccine should not be given to you if you have a concurrent illness or are convalescing.

A single booster is needed every three years while ever you are at risk. If many years have elapsed since the initial course, a single booster will be adequate.

Poliomyelitis

Poliomyelitis is endemic in many developing countries, including South-East Asia and the Middle East. Ensure protection with a booster of Sabin oral vaccine if the last dose was taken more than 10 years ago.

Infectious hepatitis (hepatitis A)

Infectious hepatitis is a definite risk in developing countries, especially if you are going off the beaten track. If you make frequent visits to developing areas, it would be worthwhile determining your anti-HAV IgG status (if positive, you are immune and globulin is not needed; if anti-HAV negative, then globulin is advisable). The duration of protection from gamma 


\section{Reducing Travel Risks}

- Continued from page 32

globulin depends directly upon the size of the dose. An adequate dose for $3-4$ weeks is $0.04 \mathrm{ml} / \mathrm{kg}$ of body weight; protection up to six months is given by a dose of $0.12 \mathrm{ml} / \mathrm{kg}$ of body weight.

Hepatitis A vaccines are currently under field trial.

Hepatitis B

For most travellers to developing countries, hepatitis B vaccine is not indicated. Risk of hepatitis B is greatly increased if you are likely to be handling blood or blood products (eg. medical research or care), are promiscuous, homosexual, a drug abuser or likely to need parenteral injections or a blood transfusion while in these countries. If so, vaccine is advisable, starting six months before departure.

\section{Hepatitis non-A and non- $B$}

Water-borne hepatitis non-A non-B occurs in the Indian subcontinent, South-East Asia, North and West Africa, Mexico and possibly China. All drinking water should be boiled (see Travellers' diarrhoea).

\section{Tuberculosis}

Tuberculosis is very common in developing countries. If the Mantoux negative traveller is spending much time, say 12 months or more, in such areas, $B C G$ vaccination is advisable. A chest X-ray up to 12 months after return may be wise.

\section{Meningococcal disease}

Meningococcal disease is prevalent in Nepal, Vietnam, Egypt, Brazil, Ghana, Burkina Faso (Upper Volta), Niger, Nigeria, Mali, Sudan, Chad, Saudi Arabia and Mongolia. A bivalent meningococcal vaccine is now available through the Commonwealth Serum Laboratories. One dose of this vaccine provides some protection against the $\mathrm{A}$ and $\mathrm{C}$ serogroups and has minimal adverse reactions.

\section{Japanese B encephalitis}

Japanese B encephalitis is a mosquito-borne virus occurring in China, Taiwan, Japan, Guam, Philippines, Korea, India, Bangladesh, Thailand, Burma and SouthEast Asia, down to and including Bali.

Vaccination is only advisable if you are planning a long stay, repeated short stays or where field exposure to mosquitoes is likely during summer months in endemic/epidemic areas. Biken inactivated vaccine is available on an Individual Patient Use basis, two or three doses 1-2 weeks apart. Enquiries: Dr Robert Hall, Commonwealth Department of Health, Canberra; tel: (06) 2898345

\section{Others}

You should be actively immunised against tetanus and diphtheria. A booster (ADT) is advisable every 10 years. Other immunisations are available for special purposes, eg. typhus fever, plague, rabies. These are usually administered to those who will be resident for at least a year in areas where such diseases occur.

\section{CHEMOPROPHYLAXIS \\ Malaria}

The global malaria situation is worsening. Malaria endemic areas are listed in Table 2, including those where chloroquine (and antifolate combination)resistant strains of falciparum occur.

Precautions against mosquito bites are an essential part of the prevention of malaria.

Anopheles tend to bite from dusk to dawn inclusive, at which time light-coloured, long-sleeved shirts and slacks should be worn. The exposed part of the skin should be smeared with an insect repellant containing DEET (diethyl toluamide), eg. RID. Mosquito nets soaked in permethrin should be used at night. These precautions are not usually necessary in major cities.

The following advice needs frequent revision because of global malaria changes (Table 2).

For the average tourist staying in cities or main towns, the recommended malaria prophylactic is chloroquine. It is effective against all species of Plasmodium except chloroquine-resistant strains of $P$. falciparum.

Dose for average size adult: Chloroquine $(150 \mathrm{mg}$ base per tablet). Two tablets by mouth once a week on the same day each week, starting one week before departure. Continue throughout stay in the endemic area and for four weeks after leaving the area.

\begin{tabular}{|c|c|}
\hline \multicolumn{2}{|c|}{ MALARIA ENDEMIC AREAS } \\
\hline Africa: & $\begin{array}{l}\text { Algeria, Angola', Benin', Bhutan', Botswana, } \\
\text { Burkina Faso', Burundi', Cameroon', Central } \\
\text { African Republic', Chad', Comoros', Congo', Cote } \\
\text { D'ivoire, Djibouti, Egypt, Equatorial Guinea', } \\
\text { Ethiopia', Gabon', Gambia', Ghana', Guinea', } \\
\text { Guinea-Bissau, Kenya', Liberia', Madagascar', } \\
\text { Malawi', Mali', Mauritania', Mauritius, Morocco, } \\
\text { Mozambique', Namibia', Niger', Nigeria', } \\
\text { Rwanda', Sao Tome, Senegal', Sierra Leone', } \\
\text { Somalia', South Africa', Sudan', Swaziland', } \\
\text { Togo', Uganda', United Republic of Tanzania', } \\
\text { Zaire', Zambia', Zimbabwe'. }\end{array}$ \\
\hline $\begin{array}{l}\text { Central } \\
\text { America: }\end{array}$ & $\begin{array}{l}\text { Belize, Costa Rica, El Salvador, Guatemala, } \\
\text { Honduras, Mexico, Nicaragua, Panama!. }\end{array}$ \\
\hline $\begin{array}{l}\text { South } \\
\text { America: }\end{array}$ & $\begin{array}{l}\text { Argentina, Bolivia', Brazil2, Colombia }{ }^{2} \\
\text { Dominican Republic, Ecuador', French Guiana', } \\
\text { Guyana', Haiti, Paraguay, Peru, Suriname?2, } \\
\text { Venezuela'. }\end{array}$ \\
\hline Middle East: & $\begin{array}{l}\text { Afghanistan', Iran', Iraq, Oman, Saudi Arabia, } \\
\text { Syria, Turkey, Yemen, United Arab Emirates. }\end{array}$ \\
\hline Asia: & $\begin{array}{l}\text { Burma } 2 \text {, China', Dem. Kampuchea } 2 \text {, Dem. } \\
\text { Yemen, Indonesia2, Lao People's Dem. Republic', } \\
\text { Malaysia', Sri Lanka', Thailand', Vietnam?' }\end{array}$ \\
\hline $\begin{array}{l}\text { Indian Sub- } \\
\text { continent: }\end{array}$ & Bangladesh', India', Nepal', Pakistan', Sri Lanka'. \\
\hline Oceania: & $\begin{array}{l}\text { Papua New Guinea², Philippines', Solomon } \\
\text { Islands', Vanuatu². }\end{array}$ \\
\hline
\end{tabular}




\section{Reducing Travel Risks}

\section{Continued from page 33}

For anyone who reacts adversely to the 4-aminoquinolines, alternative drugs are:

\begin{tabular}{l|l} 
proguanil $200 \mathrm{mg}$ daily (proguanil is currently \\
not available in Australia); or \\
doxycycline $100 \mathrm{mg}$ daily (tetracyclines are \\
contra-indicated in pregnancy and in children).
\end{tabular} For those who will be spending a lot of time in village settings or for those whose work involves "roughing it" in areas where chloroquine-resistant falciparum strains occur (Table 2), drug prophylaxis should be chloroquine plus Maloprim (dapsone $100 \mathrm{mg}$ plus pyrimethamine $12.5 \mathrm{mg}$ ) once weekly. As with chloroquine, start one week before departure, continue throughout stay and for four weeks thereafter.

Fansidar is not recommended as a prophylactic because of the risk of Stevens Johnson syndrome.

In those areas with strains of falciparum resistant both to chloroquine and antifolates (Table 2), either mefloquine (Lariam) $250 \mathrm{mg}$ once weekly or doxycycline $100 \mathrm{mg}$ daily are advisable.

Mefloquine is a quinine analogue effective against chloroquine and antifolate-resistant strains of P. falciparum. It appears to be relatively non-toxic. Occasionally, disorders of equilibrium or co-ordination may occur and some people may suffer psychological disturbance. Half life 21 days.

Dosage: Mefloquine $250 \mathrm{mg}$ once weekly starting a week before departure, weekly while in malarious areas and continuing for two weeks after leaving endemic areas.

\section{Other Health Measures}

Avoid mosquito bites. Mosquitoes can transmit malaria, dengue, yellow fever, Japanese encephalitis and filariasis.

\section{Travellers' diarrhoea}

Diarrhoea is a bane of many travellers. Most travellers' diarrhoea is due to enteropathic strains of Escherichia. coli. Such diarrhoea usually lasts two or three days and is self-limiting. Many other organisms can cause diarrhoea, including Salmonella, Shigella, Campylobacter, Vibrio spp, B. cereus, etc.

Food

In Eastern countries, avoid uncooked salad vegetables because these are commonly fertilised with human night-soil which may contain gut pathogens, including amoebic cysts. It is wiser to eat cooked foods served hot. Eat boiled rice rather than fried rice, and fruit that you can peel yourself.

\section{Drinks}

If uncertain about the water, convert it into tea or coffee. Boiling for one minute will kill pathogens.

Bottled, carbonated drinks are usually bacteriologically safe if bought from a reputable retailer.

Water from a hotel tap should be safe for brushing teeth or rinsing dishes.
Freezing does not sterilise; ice and ice-cream may be sources of infection.

Milk and cheese

It is best to avoid milk and locally made cheese in

Mediterranean countries, eg. Malta, Greece, etc.

Some may be infected with Brucella melitensis.

Medication

Prophylactic antibiotics against travellers' diarrhoea are not generally recommended, except perhaps for a brief stay (say up to 14 days). Doxycycline $50-100 \mathrm{mg}$ daily has been shown to reduce travellers' diarrhoea attack rates for up to 14 days.

Take a few sachets of Gastrolyte or Repalyte for electrolyte replacement for severe diarrhoea. These are useful, especially for children.

Tablets of codeine phosphate $30 \mathrm{mg}$ are light to carry, not bulky and give some relief from most attacks of diarrhoea. Some people find that Lomotil or Loperamide tablets suit them better. Use these sparingly.

Enterovioform is contra-indicated because of reported radiculo-myelopathy.

An attack of bloody diarrhoea may be due to Shigella for which tetracycline, ampicillin, Septrin or ciprofloxacin may be effective; or Campylobacter for which ery thromycin is the drug of choice. Ciprofloxacin $500 \mathrm{mg}$ bd is active against most bacteria causing diarrhoea, including Campylobacter. In cholera-endemic areas where there is risk of infection, tetracycline capsules $250 \mathrm{mg}$ twice daily or doxycycline $100 \mathrm{mg}$ daily are reasonably effective prophylactics.

Uncooked meat or fish

If possible, avoid eating uncooked or undercooked meats or fish as a number of parasitic diseases are transmitted in this way (Trichinella, Clonorchis, Taenia, Toxoplasma, etc.). Uncooked shellfish may carry typhoid, polio, hepatitis A, Norwalk agent, Vibrio spp, etc.

\section{Other hazards}

General

A small bottle of eye drops, eg. chloramphenicol, will usually control conjunctivitis. A supply of antibiotic ointment or powder such as Neotracin, Neosporin or Cicatrin is useful for minor skin infections. Those prone to tinea may wish to carry powder or tincture of Asterol, Tinaderm or clotrimazole.

\section{Bathing}

Do not swim or wade in fresh water holes, streams and rivers in Schistosome areas, eg. Africa, Malagasy, Middle East, Thailand, Philippines, Japan and China. Sea bathing does not carry this risk.

Animals

Avoid fondling or feeding stray animals (cats, dogs, monkeys, etc.) or allowing them to lick you. Rabies is endemic in many countries. If bitten, wash the wound immediately with water and cetrimide (Cetavlon) or soap. Arrange for an injection of rabies immune 


\section{Reducing Travel Risks}

\section{Continued from page 34}

globulin (RIG) and a course of human diploid cell rabies vaccine (HDCV). If these are not available, rabies antiserum (equine) and Semple vaccine may need to be used.*

\section{Footwear}

Do not walk barefoot in Third World countries (except on the sand of sea beaches) because of the risk of hookworm and strongyloides. Always wear shoes on coral reefs.

STDs

Be aware that in many Third World countries, there are STDs even more unpleasant than those found in Australia, eg. granuloma inguinale or LGV. In Africa, AIDS is especially prevalent in urban populations. In the Philippines and Thailand, antibiotic-resistant gonorrhoea is rife, as well as AIDS. Hepatitis B is a high STD risk in all developing countries.

Condoms, correctly used, do provide some protection against AIDS and gonorrhoea, less against non-specific urethritis and syphilis. Abstinence is the only certain protection.

\section{Clem Boughton, Prince Henry Hospital and University of NSW.}

*The U.S., Australian or British embassies may be able to provide information concerning RIG and HDCV.

1. "Vaccination Certificate Requirements for International Travel", WHO Geneva. Available from Hunter Publications, 58A Gipps Street, Collingwood Vic 3066. Published annually.

2. "Health Information for International Travel". Supplement to Morbidity and Mortality Weekly Report, U.S. Department Health, Education and Welfare. Public Health Service Centers for Disease Control, Atlanta, Georgia. Published annually.

3. "Malaria Guidelines for Medical Practitioners" National Health and . Malaria Guidelines for Medical

Medical Rervice. ommonwealth

Department of Health. Australian Government Publishing Service, Canberra, 1986. Periodically revised.

\section{FACT SHEETS}

Health Public Affairs is developing information sheets on measures that can be taken to reduce health risks to travellers.

They contain information on malaria, AIDS, rabies, hepatitis B and bowel upsets. Currently, there are fact sheets for the Philippines and Thailand. There are plans to extend the range to include other countries.

The sheets will be made available to HPUs for distribution.

\section{TABLE 3}

INFECTIOUS DISEASE

NOTIFICATIONS, NSW,

to end of March 1991

\begin{tabular}{|c|c|c|c|c|c|c|}
\hline \multirow{3}{*}{ DISEASE } & \multicolumn{6}{|c|}{ Number of Cases Notified } \\
\hline & \multicolumn{3}{|c|}{ Period } & \multicolumn{3}{|c|}{ Cumulative } \\
\hline & $\begin{array}{l}\text { Feb. } \\
1990\end{array}$ & $\begin{array}{l}\text { Feb. } \\
1991\end{array}$ & $\begin{array}{c}\text { March } \\
1991\end{array}$ & $\begin{array}{l}\text { Feb. } \\
1990\end{array}$ & $\begin{array}{l}\text { Feb. } \\
1991\end{array}$ & $\begin{array}{c}\text { March } \\
1991\end{array}$ \\
\hline AIDS & 23 & 20 & - & 57 & 34 & 34 \\
\hline Acute viral hepatitis & - & - & 34 & - & - & 34 \\
\hline Anthrax & - & - & 1 & - & - & 1 \\
\hline Arboviral infection (NOS) & & 3 & 7 & 1 & 4 & 11 \\
\hline Brucellosis & 2 & - & 1 & 2 & - & 1 \\
\hline Campylobacter infection & 161 & 99 & 47 & 357 & 237 & 284 \\
\hline Chlamydia & 42 & 24 & 30 & 102 & 48 & 78 \\
\hline Cholera & - & - & - & - & - & - \\
\hline Diphtheria & - & - & - & - & - & - \\
\hline Foodborne illness & 1 & - & 10 & 1 & 2 & 12 \\
\hline Gastroenteritis (inst) & - & - & 11 & - & - & 11 \\
\hline Genital herpes & 102 & 26 & 19 & 195 & 74 & 93 \\
\hline Giardiasis & 81 & 34 & 31 & 132 & 78 & 109 \\
\hline Gonorrhoea & 36 & 24 & 29 & 90 & 37 & 66 \\
\hline Haemophilus influenzae & 6 & 3 & 4 & 7 & 6 & 10 \\
\hline Hepatitis A & 2 & 6 & 2 & 7 & 16 & 18 \\
\hline Hepatitis B & 29 & 30 & 16 & 86 & 103 & 117 \\
\hline Hepatitis C & 2 & 2 & 3 & 4 & 24 & 27 \\
\hline HIV inf. & 136 & 47 & - & 306 & 162 & 162 \\
\hline Hydatid disease & - & 1 & - & - & 1 & 1 \\
\hline Infantile diarrhoea & 5 & - & - & 11 & 1 & 1 \\
\hline Legionnaires' disease & 1 & 2 & 2 & 10 & 4 & 6 \\
\hline Leprosy & - & - & - & - & - & - \\
\hline Leptospirosis & 7 & 4 & - & 12 & 12 & 12 \\
\hline Malaria & 14 & 4 & - & 35 & 4 & 4 \\
\hline Measles & 2 & 10 & 9 & 10 & 23 & 32 \\
\hline Meningococcal infection & 3 & 2 & - & 8 & 9 & 9 \\
\hline Mycobacterial disease & 34 & 1 & 6 & 109 & 7 & 13 \\
\hline Non specific urethritis & 124 & 111 & 114 & 265 & 212 & 325 \\
\hline Pertussis & 18 & 2 & - & 68 & 6 & 6 \\
\hline Poliomyelitis & - & - & - & - & - & - \\
\hline Q fever & 15 & 2 & 8 & 28 & 5 & 13 \\
\hline Rabies & - & - & - & - & - & - \\
\hline Ross River fever & 25 & 23 & 27 & 36 & 50 & 77 \\
\hline Salmonella infection & 70 & 107 & 117 & 168 & 273 & 400 \\
\hline Shigella infection & 14 & 7 & 2 & 38 & 20 & 22 \\
\hline Syphilis & 27 & 50 & 9 & 54 & 86 & 95 \\
\hline Tetanus & - & - & - & - & 1 & 1 \\
\hline Typhoid \& paratyphoid & 4 & 22 & - & 8 & 25 & 25 \\
\hline Viral haemorrhagic fevers & - & - & - & - & - & - \\
\hline Yellow fever & - & - & - & - & - & - \\
\hline Yersinia infection & 8 & 11 & 7 & 24 & 28 & 35 \\
\hline
\end{tabular}

NOS Not Otherwise Specified

inst institutional 